\title{
Revisiting the Nordic welfare model; museums and disability in the Nordic countries
}

\author{
Diana Walters* and Sari SalovaARA*
}

\begin{abstract}
This article considers the position of deaf and disabled people within the museum and heritage sectors of the Nordic countries. Recent approaches to access for deaf and disabled people have been rooted in models from the USA and the $U K$, and less attention has been given to countries with a welfare model approach. The article outlines the features of the welfare approach and the position of deaf and disabled people. It considers approaches to disability and access issues through both case studies and through official policy publications. It argues that although the economic position of disabled people is relatively good, access to cultural heritage remains patchy and uninteresting. Museums approach this as a question of physical access rather than engaging in more creative responses based on dialogue and partnership. It concludes that museums have some way to go before they will be truly accessible for deaf and disabled people.
\end{abstract}

Key words: Disability, welfare model, access, museums, heritage.

INTRODUCTION: A QUESTION OF DEFINITION

There is some debate over the definition of a Nordic welfare model. The Nordic countries are defined here as Denmark, Finland, Iceland, Norway and Sweden. Differences between their welfare models exist, in terms of legislation, application and procedures, and where these are relevant to disability and culture, they will be considered here. However, it is possible to identify the main characteristics of a generic Nordic model and the core values that make it distinct. Nordic disability policies have been included within the principles of solidarity, risk sharing, integration and normalization. The primary one of these is the notion of security, underpinned by 'collective risk sharing' (Anderson et al 2007: 14), which means that individuals (whether disabled or not) are protected by the state against poverty, ill health and homelessness. The notion of a social contract, whereby payment of high taxes during employment secures a 'cradle to the grave' welfare system is, according to Anderson et al (ibid: 38), the key feature of the model.

The Nordic countries are indeed well-known for their 
32 big welfare states and high tax rates. Social insurance and protection systems have a broad coverage and are highly inclusive or 'universal' in the sense that all citizens have, as a matter of legal right, certain entitlements in the case of eventualities like sickness, disability or unemployment.

Anderson et al (ibid) also explore the view that the origin of the egalitarianism of the Nordic model lies in the relative homogeneity and small size of the populations of the countries, leading to favourable conditions for trust in community and government. Equally, the competitive international advantage of the Nordic countries is often explained with glossy arguments that are grounded in truth but tend to show things in the best possible light.

The shared Nordic values are equality, trust, proximity to power, inclusion, flexibility, respect for nature, the Protestant work ethic and aesthetics. These values are connected with our social system and contribute to many fundamental institutional similarities between the countries, with the balance between the community and the individual being of central importance. (Norden som global vinderregion 2005: 92).

Threats to the Nordic model and its possible dissolution are the subject of increasing discussion, especially the challenges produced by population aging, immigration, climate change and changing competitive settings. One of the proffered solutions has been "flexicurity", a concept that has emerged in European Union employment and social policy (European Commission: 2007a). Flexicurity means a balance of flexibility and security in the labour market, with the objective of upholding competitiveness, employment and work satisfaction. In Denmark this approach has been de- veloped since the 1990s. People who are capable of working to some extent are guaranteed the chance to work as their working capacity allows, on public support. However, Cooper (2006: 29) argues that the generous benefits of the system are often exploited and that the use of disability and sickness pay as permanent income is high, and Hytti (2008: 10) observes that the over-usage of the system of disability benefits and job creation schemes is called the 'Swedish disease'.

This chapter will consider the Nordic model as it relates to deaf and disabled people and access to cultural heritage, predominantly defined here as access to museums and art galleries. The definition of a Nordic model used here is that of a system based on the core values outlined earlier; notably solidarity, risk sharing, integration and normalization, but with the understanding that this is also a model that is in various states of flux. Pressure on both welfare systems and museums mean that a static definition of a Nordic model is not possible.

The chapter will have an emphasis on Finland and Sweden as these are the two countries that the authors work in, and this will be reflected in the examples used throughout.

\section{DISABILITY AND THE NORDIC MODEL}

The main characteristics of the Nordic model outlined above would lead to an assumption that in terms of benefit levels deaf and disabled people in the Nordic countries are treated more favourably compared to other western nations. The disability friendly environment in the Nordic countries is apparent even to a passing traveller; the Scandinavian Europe section of the Lonely Planet travel guide states that 'Scandinavia, apart from Green- 
land, leads the world in terms of facilities for disabled people' (Cornwallis et al 2003: 28). This is in sharp contrast to Hvinden (2004: 174) who states that evidence from Nordic government reports and organisations for disabled people show that the Nordic countries are 'lagging behind' other Western countries in terms of accessibility and universal design. Hvinden (ibid: 171) also argues that the Nordic approach has relative success in economic terms, but this is not extended to employment or equal participation generally. European Union (EU) statistics demonstrate benefits to be of a high comparative level; for example, a recent study showed that disabled people in Denmark had the highest number of hours of personal assistance in the home across the EU (European Commission 2007b: 107). The Eu-ropean Commission report also cites differences between the Nordic countries, for example in the ratio between cash benefits (supporting independent living) and benefits in kind (ibid: 114) demonstrating different approaches to provision, which may have relevance for the position of deaf and disabled people within society and questions of empowerment. The same report also states that Denmark is the only EU member state that does not allow personal budgets to people with 'mental disabilities' (ibid: 110).

Traustadóttir (2004) argues that the Nordic model is more accurately a 'family of ideas'. She states that there is a tradition amongst Nordic researchers to adopt a variety of approaches to disability and not be tied doctrinally to orthodoxy. Taking a pragmatic approach to disability can be problematic, particularly when aligned to normalization, as it potentially reduces disability to levels of provision rather than a broader, more individual approach, based on identity, rights and diversity. Normalization is defined simply as the belief that inclusion and equality are achieved through deaf and disabled people becoming part of the mainstream of society. Application of this can affect freedom of choice and arguably reduces deaf and disabled people's rights to self expression and empowerment. In Sweden, levels of assistive technology are high, and the country is often used as an example of excellence in this area (Provision of assistive technology in Sweden: 2008). For example, there is free provision of walking frames to all who need them. However, some researchers argue that the law governing assistive technology in Sweden ${ }^{1}$ does not aid empowerment.

As a researcher in the field of social aspects of technical aids, I have come across more hindrances than empowerment. For instance, if you need a wheelchair, you do not have any influence on the type of wheelchair, or the colour of the wheelchair, and the decision on which wheelchair you are supplied cannot be appealed. (O Krantz 2008, pers. comm. 8 September).

The Nordic Centre of Excellence (2008) has a research strand reassessing the Nordic welfare model which includes a consideration of exclusion of deaf and disabled people. They raise the question of whether the Nordic model in fact masks exclusion, referring to low levels of employment. Certainly the power of the 'expert professional' (doctor, service provider) in determining levels of disablement and need coupled with weak anti-discrimination legislation reduces the power of redress. Trends such as a move back towards segregated education lead to a questioning of the central normalization principle. Historically, normalization had a far more sinister impact in the policy of sterilization within the Nordic countries. Broberg and Roll-Hansen's (1997) exposure of 
34 the widespread use of eugenics led the Swedish government to begin a process of compensation for many of the victims. Accounts make for harrowing reading, including sterilization of visually impaired children deemed to be 'mentally retarded'.

However, the pragmatism of the Nordic approach is often regarded as a better way than a system based on litigation as the politicisation of access can also lead to segregation. A culture of dialogue is more prevalent with deaf and disabled people active in their pursuit of civil rights, and although direct action (for example) takes place, there is an overall impression that deaf and disabled people are more passive in the Nordic countries compared to the US and the UK. Others argue that the consensus basis of the Nordic model is in fact a manifestation of compromise, and that as a consequence, activism dies (S Berg, 2008, pers. comm., 25 September). In Berg's view the existence of organisations like Handisam ${ }^{2}$ the Swedish agency for disability policy coordination are there to prevent litigation and as government funded agencies their role is to protect the status quo.

The emphasis within the Nordic model is on improvement in the material aspects of deaf and disabled people's lives. That benefits are comparatively high is clear, and the system is often defended on that basis alone. However, the view of deaf and disabled people as individuals with preferences and life style choices is limited. This has important ramifications for culture and heritage generally, as the quality of life debate rarely extends to this arena. Nordic and national heritage based initiatives exist, but the basic level of service delivery within the cultural heritage sector remains largely an aspect of choice and priority for individual institutions.
TOGETHER AND INDIVIDUALLY; DISABILITY, CULTURE AND HERITAGE IN THE NORDIC COUNTRIES

Nordic operating models are closely related and subject to active interaction. Geographic closeness and similarities in social structures have created traditions for cooperation and financing models that enable collaborative projects among Nordic countries. Applicants for Nordic grants are usually asked in what way their project benefits Nordic cooperation and they are used to listing such aspects as a common set of values based on equality, which the cooperation can build on. In practice, Nordic grants that support projects carried out among a number of countries are important enablers also for cultural heritage initiatives. The participants benefit from interaction since there are differences even between the familiar neighbouring countries. The networking also requires face-to-face interaction and joint projects bring people to the same table.

There are however problems concerning everyday practice. For example, the lack of a common language can create problems in communication. It is part of the Nordic tradition to favour the use of the Scandinavian languages, but in practice the differences between the languages and the exceptionality of the Finnish language cause some friction. Everyone could of course communicate in English, but an outside language is not easily consented to which can lead to a situation where people are not able to understand each other. Representatives from different countries may get together, for example, in a project promoting equality, but can at the same time fail to reach equality in their mutual communication.

The Nordic Council on Disability Policy ${ }^{3}$ 
and its sector network for culture has played a significant role in initiating projects. The council is a policy-shaping and advisory body appointed by the Ministers for Nordic Cooperation. It has done much useful work in rendering the aspect of disability visible, acting as a mediator between cultural administration and cultural operators, applying for finance, and compiling comparative information on the Nordic countries. The work of the Council can, however, be criticized for the fact that very few of its employees or representatives of the different countries in its member network are deaf or disabled people. The positive impression of work well done is dented when the principle launched by the disability movement 'nothing about us without us' is often left unrealised.

The data that the Council has published includes information on disability policy actions in different Nordic countries in the field of art and culture. The 2004 publication entitled 'Nordic News - From project policy to an inclusive cultural policy?' ${ }^{4}$ states that the individual countries have put in variable performances but the clear trend is towards 'culture for all' (Nordic Cooperation on Disability NSH: 2004). Yet there still has been an emphasis on project work as opposed to a remodelling of the infrastructures to produce inclusive cultural policy and actions in a consistent or sustainable way. Equally, there is no consistency between the various policies of the Nordic countries or their level of enforcement. Some key developments are outlined below.

In Norway, existing building law will be replaced by a new act in 2009 which will require a universal design approach and a far higher level of access to museums. The Discrimination and Accessibility Act equates lack of ac- cessibility to discrimination, representing a potentially significant shift in priority and understanding (Olsen 2008: 3).

In Sweden, the national initiative in access for disabled people contains an action plan that requires implementation by 2010 (Regeringskansliet: 2000). Entitled 'From Patient to Citizen - a national action plan for disability policies's the plan extends to museums and cultural organisations. Both the National Heritage Board and the National Council for Cultural Affairs have been given 'special sectoral responsibilities for disability issues' (ibid: 10). However, the overall approach is built on the notion of devolved responsibility, thus

Each institution makes its own decisions about the orientation its activities should follow. Cultural institutions in the state sphere and institutions that receive government grants, however, bear particular responsibility for seeking new ways of reaching categories of people who do not currently share in the cultural activities on offer in the country. Government grants are therefore an important factor in enabling the disabled to benefit from cultural activities in the public sphere. Studies have shown that accessibility has increased in recent years but much progress remains to be made before the goals are achieved. (ibid: 21).

The ability of culture to combat prejudice is also recognised although there are no clear objectives relating to this (ibid: 20). The principle of anti-discrimination for deaf and disabled people does not extend to a discreet law in Sweden. Disability appears in three other laws which established rights for deaf and disabled people in the area of independent living, planning, buildings and social services (Swedish Institute: 2006). Ineland (2005: 749) describes disability policy in Sweden as 'ambitious and supported by the principles of influence, 
36 participation, independence and self determination'. Ironically this can lead to complacency. A government document stated that 'in comparison with other countries Sweden has high demands on accessibility and usability for persons with disabilities - maybe even the highest in the world when it comes to housing' (SOU 1994: 36). However, the document states that buildings can be regarded as accessible that have 'easy obstacles', defined as a maximum of two steps; difficult to accept if you are a wheelchair user.

Denmark is unique in its implementation of an 'accessibility label' that guarantees a minimum level of access to public buildings. However, the approach adopted is based on seven 'categories' of disability, each one of which can be awarded a label ${ }^{6}$. The effect of this could be that segregation is unwittingly reinforced, as certain groups of deaf and disabled people may receive a higher level of access leading to a disability hierarchy. The labels distinguish between impairment and disability is viewed in broadly medical terms. This is in opposition to a social model approach that would start with the definition of barriers within the environment. On the website, ${ }^{7}$ museums are listed under 'attractions in buildings', which make them a little difficult to locate (libraries, for example, have a separate listing). However, the available fact sheet for each museum is extremely detailed and has an excellent level of practical information; making no assumptions about levels of access and allowing visitors to exercise informed choice. In terms of law, the Danish Museums Act (2001) includes the clause 'the museum shall aim to ensure the greatest possible accessibility for the disabled', although no enforcement exists relating to this.

In Iceland, the museums are currently audi- ting their levels of access and the National Museum dedicated 2008 to resolving questions of accessibility. The focus has been on practical improvements such as audio guides, Braille and access information. Accessibility is quite new on the museums' agenda and there is a general worry that funds will not be forthcoming to support any sustainable changes in provision.

In Finland, the year 2000 signalled an awakening in the cultural administration to extend and accommodate the principles of equality to the field of cultural services. The work of the Ministry of Education and Culture proceeded in three stages: firstly, a working group was appointed to evaluate cultural participation among deaf and disabled people and supportive administrative measures. Secondly, the Disabled People and Culture Committee was appointed to prepare an action plan (Ministry of Education: 2004) to support operators so that deaf and disabled people were better taken into consideration as producers and consumers of culture. The committee comprised representatives from the state administration, the municipal sector, cultural institutions and organizations for deaf and disabled people. The third stage centred on the Access to Arts and Culture for All' programme in which the Ministry of Education outlined its measures for the five-year period of 2006-2010 (Ministry of Education: 2006). The suggested measures primarily concerned resource allocation, information-based guidance and performance management. For example, state allowances have been directed to making audits and forming strategies in order to encourage strategic approaches instead of delivering short term projects. In the programme, the perspective on accessibility was extended to cover not only that of deaf and disabled people but also 
the views of other groups including immigrants, language and cultural minorities and older people. It remains to be seen if this leads to a diminishing of resources specifically for deaf and disabled people within a broader operational framework.

As one of its information-based guidance measures, the Ministry of Education and Culture finances an information service for producers of cultural services. Since the Finnish National Gallery has built up experience and shown interest in promoting the accessibility of the arts over several decades, the service is based in its Department of Communication Relations and Development. Key actors in the museum field have cooperated with the Finnish National Gallery in producing this service.

The service's task is to enhance cultural accessibility through the establishment of networks and communication contacts, needs assessments, training and production of materials. The information service provides tools, guidelines and expertise to support cultural service producers. An important channel for sharing information is the Culture for All website, ${ }^{8}$ which also acts as a central anchor for the accessibility network of Nordic museums described below.

\section{Nordic Museums fOR AlL}

The 'Nordic Museums for All' project ran between 2000 and 2003 and launched cooperation among museums around the questions of accessibility. Participators in the project included various Nordic museums and representatives from different groups of deaf and disabled people. The key outcomes were an Accessible Museum Guidebook for museum staff, an accessibility evaluation tool for use in museums, an international 'Museums for All' conference and a touring exhibition.

Nordic museum professionals have continued this co-operation. The Culture for All service, run by the Finnish National Gallery, administers a website and mailing list, and each year a different museum in a different Nordic country takes responsibility for appointing a contact person and updating the information. Currently, nearly 50 museums have signed up as members of the network, wishing to provide and share information about their services. The network was under the management of Sweden in 2008 and in 2009 Iceland will have the coordinating role. The objectives of close communication, easy exchange of experiences and better information resources are being realised slowly and by a fairly small network as commitment to the network is low and other priorities tend to take precedence. Individuals with an interest in access issues are most active, suggesting that museums as institutions do not prioritise this work. There is also a tendency to avoid anything controversial and focus more on information rather than debate. This is also mirrored in the accompanying list, which despite a growing membership of about 260 individuals (November 2008) continues to have very low activity. Only Finland regularly posts information on the list and discussions are rare. Finland's more active role in the network is largely because the initiative originated there and also because of individuals who have assumed responsibility for this area of work.

The issue of availability and deployment of resources is also important. The Nordic countries have not embraced the inclusion paradigm to the extent that, for example, the UK has. Therefore, the swathe of jobs relating to access and outreach activity within the mu- 
seum sector that has so defined the last decade in the UK has not been mirrored on the other side of the North Sea. Access has a lower profile within the museum sectors, though there are signs that it is emerging. Arguably, integrating access into all aspects of museum activity is a far more effective way of achieving inclusion with responsibility not contained within specific posts; but this has to be aligned to clear strategic objectives for a cultural shift to inclusion within the whole organisation. The devolved approach al may thus mean that sector initiatives are not easily adopted by individual museums, leading to a position of good policies being largely unimplemented. The role of the individual as an agent of change is therefore crucial at this time, as are the voices of deaf and disabled people themselves.

There are several recent studies in Finland that have asked museums about their work with access or inclusion. The Finnish Ministry of Education and Culture conducted a survey of the accessibility work of the 134 museums receiving state subsidies. In 2007 the museums had engaged in more cooperative projects with deaf and disabled people than with other 'minority' groups (particularly ethnic and sexual). It is also interesting that some of the museums stated that they had not paid any attention to questions of accessibility, even when their staff included representatives of minority groups.

A majority of Finland's 1000 museums are small, local cultural history museums, and often do not have any permanent staff. These museums, frequently based in old, non-accessible buildings, have very rarely known how to make use of the possibilities they have; for example, to offer audiences tactile material. In another survey among non-professionally ma- naged small museums carried out by the Finnish Museums Association in 2008, 31 of the respondents said that their exhibitions included tactile objects, and only 15 of the museums could provide unobstructed access to all their facilities. Fortunately the situation is more encouraging in larger professional museums, but even there results are disappointing. The way in which museums relate to disability issues in Finland can be characterized as quite traditional. Efforts have been made in recent decades to develop the accessibility of museums to disabled audiences, but the question has not been tackled with sufficient dynamism when it comes to content. Interestingly attitudes have traditionally been positive towards deaf and disabled people than other oppressed minorities in Finland due to the huge number of causalities in the Second World War (2.5\% of the population became disabled), ${ }^{9}$ and this has continued to contemporary times. However museums centring on war history tend to deal with disability as a medical issue and the general history of deaf and disabled people is seen as a natural part of the development of social welfare.

Salovaara (2007) assessed the impact of a project grant allocated to museums in Finland and asked 'Who has access to the museum?' The studied state subsidy was aimed at developing accessibility, enhancing multiculturalism and tolerance and cultural heritage education. The study pointed out that the additional resource enabled new and experimental activities, but the museums were not very innovative about who they cooperated with or how much they put emphasis on the recognition of the minorities within their projects. Another problem with project based activity is its short duration, which makes it hard to as- 
sess how purposeful and sustainable the positive impacts are. All in all the study showed that the museums wanted to reach out to deaf and disabled people as visitors but rarely addressed any related historical or contemporary issues in their displays. Equally, deaf and disabled people were rarely employed and exhibitions and collections did not draw out hidden histories.

Rajavuori (2008) is researching the perspective of Nordic museum professionals on promoting accessibility. She points out that even though society steers the museums with legislation and policy programmes, what actually happens in the museums still largely depends on individuals, on their level of interest and awareness.

\section{DIVERSE APPROACHES, DIFFERENT OUTCOMES}

Inevitably, there are differences between the Nordic countries in terms of trends and levels of activity in the field of disability and access. This section describes some examples of initiatives taken in some Nordic museums, and there are many more. The existence of the Finnish National Gallery and the leadership role taken there means that there is an impression of more activity in that country. The Norwegian Archive, Library and Museum Authority $^{10}$ (ABM utvikling) is embracing disability more and more within its core activity. However, the museum sectors as a whole have not championed disability as a discreet issue and levels of professional development and understanding are also quite low. Generally, it is fair to say that the emphasis has been far more on areas of physical access to buildings. This is in line with developments in the US and the UK where the main focus of change began with physical and to a lesser extent sensory access to buildings and exhibitions (Walters 2008). However, in the aforementioned countries the process of opening up museums to deaf and disabled people is underpinned by legislation, which in the case of the UK continues to be strengthened. ${ }^{11}$ In responding to this, and through a general process of audience development, museums have begun to adopt a definition of access to include issues of representation and hidden history; though one possible consequence of this is that it may allow museums to undertake a more traditional museum role based in collections and exhibitions rather than actively working for empowerment of deaf and disabled people through partnerships based on contemporary issues around discrimination. In the Nordic countries, the process in this area is less developed. Projects tend to be focused more on practical solutions rather than any paradigm of inclusivity supported by material culture. However, there are signs that interest in representation issues is growing. Kaitavuori (2008) from the Finnish Museum of Contemporary Art, Kias$\mathrm{ma}$, states that it is time to put more emphasis on participation. According to her, museums need to be seen as a public space and the idea of participation gives a new dimension to accessibility:

There is a clear difference between the approach of producing programmes and events for an audience and the approach of giving space for an audience to make their programme. In the first case people (or the target group) are considered audience, in the latter they are actors or users. In the participatory approach the people outside the museum are seen as mature citizens who have opinions and things to say about the museum, and who have their own relationship with the content of the museum, as well an understanding 
about the meaning of the museum in their own life and in society. (Kaitavuori 2008: 7).

Arguably, Finnish art museums have been leading innovative approaches to disability issues. In past decades, many art museums around the country have organized exhibitions and events connected with deaf and disabled people and art. What these museums have had in common has been the pedagogic capacity and interest of the staff to cooperate with, for example, organisations for deaf and disabled people or individuals or groups representing disabled artists. The Hyvinkää Art Museum, for example, has held various exhibitions featuring the art of people with intellectual disabilities and mental health care clients, including discussions and workshops. Also, the Ateneum Art Museum has received international acclaim for the film festivals it has organized together with an organization for disabled people since 1997, which deal sharply with questions of disability; they also host an international short film competition.

In Iceland, museums have gradually started to cooperate and gain experience in promoting accessibility. One of the forerunners in the field has been the National Museum of Iceland. For example, the museum carried out a project together with the renowned US photographer Mary Ellen Mark in 2005-2006. Mark is known for her striking portraits and photojournalism with a strong social message. She photographed the everyday lives of children with intellectual disabilities, especially in two special education schools. The photographs were compiled into a travelling exhibition and copies of them were included in the museum's collections. The museum also published a book on the project, which combined Mark's photographs, various writings, paintings by the children and photographs school premises by an Icelandic photographer (Ingólfsson 2007).

The positive aspect of the project, from the perspective of the disability movement, is that the photographer featured the children as strong personalities in different emotional states. There was no room for stereotypes, and the children were strongly visible and close to the viewer in the pictures. In the writings published in the book, the children's parents speak of daily life and compare, for example, the advantages and disadvantages between special education schools and ordinary schools. Expression is given to the right of all children to decent life and Mark notes in the book that she does not want to embellish the fact that life can also be hard. The one thing missing in the project are comments from the children themselves, quoted opinions, since surely many of them had their own perceptions of the project or of being at school, which could have been expressed in writing. The book could also have included the thoughts of deaf and disabled adults. It would have helped to shake off the impression that the book was made about disabled "others".

A Swedish example, from 2003, shows how disabled people's voices can create an exhibition discourse that reveals often uncomfortable testimony and compels visitors to question their attitudes. The exhibition, entitled 'Tänk Om?'12 encouraged deaf and disabled people to record aspects of their daily lives rather than focussing overtly on exclusion or discrimination. The result was to make the narratives more powerful; daily experiences of individuals formerly institutionalised or outside of mainstream 'normal' society highlighted the obvious inequalities in a country that prides itself on its egalitarianism. The exhibition was 
one of a series of small shows prior to the opening of the World Culture Museum in Gothenburg in 2004.

One hope of the organisers of Tänk Om was that the experience of the exhibition might be carried forward into the culture of the organisation generally. However, this did not happen to any real extent. Deaf and disabled people continue to encounter barriers in a new museum building and issues of representation have not been furthered. Within the museum, diversity does not appear to extend to deaf and disabled people beyond physical access.

More recently, Vasa Museum in Stockholm redesigned its main education room to provide an integrated accessible experience for the children using it. Done in partnership with the Karolinska Institute, the room integrates rehabilitation with active learning and integration. Called 'All Onboard', the room includes tactile surfaces related to marine archaeology, an accessible lift that works as a steering mechanism for a ship and a wheelchair accessible 'upper deck' where disabled and non disabled children collaborate to drive an imaginary boat. Principles of universal design have been adapted to create a multi-functional space that is integrated, educational and fun.

Many other individual examples of access related work exist across the Nordic countries, but it is the general lack of strategy that is most obvious. Norway and Finland seem to be moving more quickly in this direction, although there are signs that disability is emerging onto the cultural agenda elsewhere. A worry is that this may not be sustained, and that initiatives still rely too much on individuals. Other agendas and priorities may emerge before commitment to inclusion for deaf and disabled people goes beyond the practical and becomes part of an agenda of cultural human

\section{CONCLUSION}

Nordic museums are on average poorly prepared to treat disability in an interesting manner, reflective and fresh perspectives being the exception. Museums need the expertise of deaf and disabled people and engagement with the disability movement in developing initiatives. As is so often the case, the emphasis on physical aspects of accessibility narrow the possibilities of more creative developments. Despite the relative economic benefits of the Nordic countries, and arguably higher levels of integration, deaf and disabled people remain largely absent from museums and the business of access is not undertaken within the paradigm of empowerment. The emphasis on material aspects of daily life relegates heritage and culture to the sidelines, as an aesthetic experience for consumption by the few. This is a general criticism of the Nordic model per se but for deaf and disabled people the exclusion is intensified as neither the expectation nor the ability exists within the museum sector to any great extent. There are some excellent exceptions to this where individuals, often with limited support, or project funding have influenced a shift in perspective. However, the Nordic museum profession, generally, does not see disability as an aspect of equality, and deaf and disabled people remain largely marginalised.

\section{ACKNOWLEDGEMENTS}

The authors wish to thank Susanne Berg and Peter Davis for their helpful comments. 


\section{$42 \quad$ Notes}

1. Health and Medical Act, $₫ 3$ and $\$ 18$ (Hälso- och sjukvårdslagen).

2. Formed in 2006.

3. See http://www.nsh.se/in_english.htm

4. Aktuellt i Norden - Frän projektpolitik till en inkluderande kulturpolitik? Translated by the authors.

5. Frän Patient till medborgare - en nationell handlingsplan for handikappolitiken. Translated by the authors.

6. See the Danish Accessibility Association website, http://www.godadgang.dk/gb/main.asp

7. http://www.godadgang.dk/gb/main.asp

8. See www.cultureforall.info

9. See http://www.vammaishistorianseura.fi/historia.htm

10. See http://www.abm-utvikling.no/?set_language $=$ en

11. For example, the Disability Equality Duty (2006) amendment to the Disability Discrimination Act (1995) requires museums as public bodies to state how they will promote equality for disabled people.

12. 'What if?' Authors translation from the Swedish was curated jointly by Susanne Berg and the Museum of World Culture, Gothenburg; Diana Walters (co author) and disability consultant Michéle Taylor produced the text.

\section{BIBLIOGRAPHY}

Anderson, T, Holmström, B, Honkapohja, S, Korkman, S, Söderström, H \& Vartiainen, J. (2007) The Nordic Model. Embracing globalization and sharing risks, The Research Institute of the Finnish Economy, Helsinki.

Broberg,G \& Roll-Hansen,N. (1997) Eugenics and the welfare state, Michigan State University Press.
Cooper, S. (2006) 'Scandinavian Irony: Socialism Meets Liberalization', The Freeman: Ideas on Liberty, vol. 56, no.7, pp. 29-33.

Cornwallis, G, Bain, C, Hannigan, D, Harding, P. (2003) Lonely Planet Scandinavian Europe, Lonely Planet Publications Pty Ltd.

European Commission. (2007a) Towards common principles of flexicurity, More and better jobs through flexibility and security, retrieved November 10th , 2008, from http://ec.europa.eu/employment_social/employment_strategy/flexicurity\%20media/flexicuritypublication_2007_en.pdf

European Commission. (2007b) Study of compilation of disability statistical data from the administrative registers of the member states. Retrieved November 8th, 2008, from http://ec.europa.eu/employment_social/index/comp_disb_final_en.pdf

Hvinden, B. (2004) 'Nordic Disability Policies in a Changing Europe: Is there still a Distinct Nordic Model?' Social Policy and Administration, vol.38, No.2, pp 170-189.

Hytti H. (2008) Disability policies and employment. Finland compared with the other Nordic Countries. 62/2008 Social Security and Health Research: Working Papers.

Ineland, J. (2005) Logics and discourses in disability arts in Sweden: a neo-institutional perspective, in Disability and Society, Vol.20, No.7, pp. 749762.

Ingólfsson, E. (2007) Extraordinary Child. Disabled children in Iceland. Photographs by Mary Ellen Mark. The National Museum of Iceland.

Kaitavuori, K. (2008) From accessibility to participation - museum as a public space, Making Cultural Heritage Truly Common, Culture for All Service, Finnish National Gallery, 2008, pp. 5-8.

Ministry of Education (2004) Taide tarjolle, kulttuuri kaikille. Vammaiset ja kulttuuri - toimikunnan ehdotus toimenpideohjelmaksi. Opetusministeriön julkaisuja 2004: no.29. Helsinki.

Ministry of Education (2006) Taiteen ja kulttuurin 
saavutettavuus. Opetusministeriön toimenpideohjelma 2006-2010. Opetusministeriön julkaisuja 2006: no. 6. Helsinki.

Nordic Centre of Excellence (2008) Combating exclusion, the case of people with Disabilities, retrieved November 8th from http://www.reassess.no/index.gan?id=14524\&su bid $=0$

Nordisk Råd, Ministerråd (2005) Norden som global vinderregion. På sporet af den nordiske konkurrencemodel. Huset Mandag Morgen. Nordisk Råd, Ministerråd, ANP 2005, no. 777.

Nordic Cooperation on Disability - NSH (2004) Aktuellt i Norden. Frän projektpolitik till en inkluderande kulturpolitik? Petrén, F, Oderstedt, I, Wiklund, L (eds). Solna. NSH - Nordiska samarbetsorganet för handikappfrågor.

Olsen, A. (2008) Can Universal Design challenge ossified attitudes and structural discrimination? Rehabilitation International Conference, Quebec. Retrieved from November 17th 2008 from http://www.shdir.no/deltasenteret/ kan_universell_utforming_rokke_ved_strukturell_institusjonell_diskriminering_236644

Rajavuori, T. (2008) Pohjoismaisten museoiden saavutettavuushankkeet - museotyöntekijän näkökulma. M.A. thesis (in progress), University of Helsinki. Regeringens Proposition, 1999/2000, Fran Patient till medborgare - en nationell Handlingsplan för handikappolitiken, retrieved July 10th 2008, from http://www.dhr.se/showFile.asp?objectId=11269

Salovaara, S. (2007) Kuka pääsee museoon. Museoviraston jakamat avustukset innovatiivisiin hankkeisiin kulttuurisen yhdenvertaisuuden edistäjänä. M.A. thesis, University of Jyväskylä.

SOU. (1994) Report from the government commission on building and planning, Allmänna Förlaget, Stockholm.

Swedish Institute. (2006) Swedish Disability Policy, retrieved July 25th 2008 from http://www.sweden.se/templates/cs/FactSheet 13508.aspx
Traustadóttir, R. (2004) Disability studies, a Nordic perspective, Disability Studies Conference Lancaster, retrieved November 10th, 2008 from http://66.102.9.104/search?q=cache:_bQQQBw r_MgJ:www.disabilitystudies.net/dsaconf2004/fu llpapers/traustadottir.ppt+nordic + model $+\% 2 \mathrm{~B}+\mathrm{d}$ isability $\& \mathrm{hl}=\mathrm{en} \& \mathrm{ct}=\mathrm{clnk} \& \mathrm{~cd}=2$

Walters, D. (2008) Attracting Zealots: Responses to disability in museum collections and practice in the early 21st century, PhD thesis, Newcastle University.

* Diana Walters is programme director for International Museum Studies MA at Gothenburg University, Sweden. She has a PhD from Newcastle University in museums and disability and has worked extensively in the field of museums and access.

Address: International Museum Studies, Göteborgs Universitet

Box 111, 40530

Göteborg, Sweden

E-mail: diana.walters@museion.gu.se

*Sari Salovaara is based at the Finnish National Gallery, Finland. She has an MA in 'Who is allowed in a museum, a study of the effect of governmental financial support aimed to promote equality in museums.

Address: Finnish National Gallery

Kaivokatu 2

FI-00100 Helsinki

FINLAND

E-mail: Sari.Salovaara@fng.fi 